\title{
PEMBUATAN PUPUK CAIR DAN BIOGAS DARI CAMPURAN LIMBAH SAYURAN
}

\author{
Erickson Sarjono Siboro, Edu Surya, Netti Herlina \\ Departemen Teknik Kimia, Fakultas Teknik, Universitas Sumatera Utara, \\ Jl. Almamater Kampus USU Medan 20155, Indonesia \\ Email : erickson.chemical@gmail.com
}

\begin{abstract}
Abstrak
Sampah hasil kegiatan pasar yang tidak mengalami pengelolaan secara baik akan menimbulkan pencemaran lingkungan. Sampah-sampah tersebut masih mengandung kadar air yang tinggi serta mengandung bahan-bahan organik berupa karbohidrat, protein, dan lemak yaitu salah satunya adalah limbah sayuran. Salah satu cara yang dapat dilakukan untuk mengelola limbah sayuran ialah dengan mencacah limbah sayuran dengan belender lalu difermentasi dengan bantuan EM4 sehingga menjadi pupuk cair organik, karena pupuk cair organik lebih cepat meresap ke dalam tanah dan cepat dimanfaatkan langsung oleh tanaman, serta tidak merusak tanah dan tanaman. Data awal yang diperoleh dari penelitian ini berupa kadar air 88,78 \%, pH 7,68, dan rasio C/N 33,56. Data akhir dengan hasil optimal diperoleh pada hari ke 25 dengan komposisi EM4 $350 \mathrm{ml}$ yaitu unsur N 1 \%, P 1,98 \%, K 0,85\% dan rasio C/N $30 \%$, total solid 34,78 \%, Chemical Demand Oxygen (COD) $2386 \mathrm{mg} / \mathrm{L}$, biogas $13 \mathrm{ml}$ dan pH 5,55.
\end{abstract}

Kata kunci: biogas, EM4, limbah sayuran, pupuk cair organik,

\begin{abstract}
.
Garbage market activity results, which are not well experienced management will cause environmental pollution. The waste of vegetables still contains a high water content and contain organic ingredients, such as carbohydrates, proteins, and fats that one of them is a waste of vegetables. One method to manage waste of vegetables is to chop waste of vegetables with use the blender and mix with EM4 then fermented for 25 days. So it becomes an organic liquid fertilizer, because more quickly absorbed into the soil and quickly be used directly by plants, and can't damage the soil and plants. Preliminary data obtained from this study of the water content of $88.78 \%, p H 7.68$, and the ratio of $C / N 33.56$. Final data with optimal results obtained on day 25 with the composition of the EM4 $350 \mathrm{ml}$ of $\mathrm{N} \mathrm{1 \% ,P} 1.98 \%, \mathrm{~K} 0.85 \%$ and the ratio of $\mathrm{C} / \mathrm{N} 30$, total solid 34.78\%, Chemical Oxygen Demand (COD) $2386 \mathrm{mg} / \mathrm{L}, \mathrm{pH} 5.55$ and $13 \mathrm{ml}$ of biogas.
\end{abstract}

Keywords: biogas, EM4, liquid organic fertilizer, waste vegetable

\section{Pendahuluan}

Sampah sayur-sayuran merupakan bahan buangan yang biasanya dibuang secara open dumping tanpa pengelolaan lebih lanjut sehingga akan meninggalkan gangguan lingkungan dan bau tidak sedap. Limbah sayuran mempunyai kandungan gizi rendah, yaitu protein kasar sebesar 1-15\% dan serat kasar 5-38\% [1].

Penggunaan Effective Microorganisme (EM4) dalam mempercepat pembuatan pupuk cair dianggap sebagai teknologi karena bertujuan untuk mempercepat proses fermentasi. Effective Microorganisme merupakan kultur campuran berbagai jenis mikroorganisme yang bermanfaat (bakteri fotosintetik, bakteri asam laktat, ragi aktinomisetes dan jamur fermentasi) yang dapat meningkatkan keragaman mikroba tanah. Pemanfaatan EM4 dapat memperbaiki pertumbuhan dan hasil tanaman [2].

Komoditas kelapa sawit memiliki berbagai macam kegunaan baik untuk industri pangan maupun non pangan/oleochemical serta produk samping/limbah. Luas area pertanaman kelapa sawit di Indonesia terus mengalami peningkatan sejak tahun 1999 hingga tahun 2006. Peningkatan tertinggi terjadi dalam kurun waktu 2000 - 2001 yaitu seluas 555,358 Ha (13.36\%) dan kurun waktu 2005 - 2006 yaitu seluas 621,109 Ha (11.39\%) [4].

\section{Teori}

Sampah organik adalah sampah yag dihasilkan dari bahan-bahan hayati yang dapat didegradasi oleh mikroba atau bersifat biodegradable. Sampah organik sendiri dibagi menjadi sampah organik basah dan sampah organk kering. Istilah sampah organik basah dimaksudkan sampah yang mempunyai kandungan air yang cukup tinggi contohnya kulit buah dan sisa sayuran. Sedangkan sampah organik kering adalah sampah yang mempunyai kandungan air rendah contoh kayu atau ranting dan dedaunan kering [3].

Bahan organik tidak dapat langsung digunakan atau dimanfaatkan oleh tanaman karena 
perbandingan $\mathrm{C} / \mathrm{N}$ dalam bahan baku tersebut relative tinggi atau tidak sama denga $\mathrm{C} / \mathrm{N}$ tanah. Nilai C/N tanah sekitar 10-12. Apabila bahan organik mempunyai kandungan $\mathrm{C} / \mathrm{N}$ mendekati atau sama dengan $\mathrm{C} / \mathrm{N}$ tanah maka bahan tersebut dapat digunakan atau diserap tanaman. Prinsip pengomposan adalah menurunkan $\mathrm{C} / \mathrm{N}$ rasio bahan organik sehingga sama dengan tanah $(<20)$. Dengan semakin tingginya $\mathrm{C} / \mathrm{N}$ bahan maka proses pengomposan akan semakin lama karena $\mathrm{C} / \mathrm{N}$ harus diturunkan [8].

Proses pengomposan anaerobik berjalan tanpa adanya oksigen. Biasanya, prosesnya dilakukan dalam wadah tertutup sehingga tidak ada udara yang masuk (hampa udara). Proses pengomposan ini melibatkan mikroorganisme anaerob untuk membantu mendekomposisi bahan yang dikomposkan. Bahan baku yang dikomposkan secara anaerob biasanya berupa bahan organik yang berkadar air tinggi [9].

Pengomposan anaerobik akan menghasilkan gas metan (CH4), karbondioksida (CO2), dan asam organik yang memiliki bobot molekul rendah seperti asam asetat, asam propionat, asam butirat, asam laktat, dan asam suksinat. Gas metan bisa dimanfaatkan sebagai bahan bakar alternatif (biogas). Sisanya berupa lumpur yang mengandung bagian padatan dan cairan. Bagian padatan ini yang disebu kompos. Namun, kadar airnya masih tinggi sehingga sebelum digunakan harus di kering anginkan [11].

Pupuk cair organik adalah pupuk yang bahan dasarnya berasal dari hewan atau tumbuhan yang sudah mengalami fermentasi dan berntuk produknya berupa cairan. Kandungan bahan kimia di dalamnya maksimum 5\%. Penggunaan pupuk cair memiliki beberapa keuntungan sebagai berikut :

1. Pengaplikasiannya lebih mudah jika dibandingkan dengan pengaplikasian pupuk organik padat.

2. Unsur hara yang terdapat di dalam pupuk cair mudah diserap tanaman

3. Mengandung mikroorganisme yang jarang terdapat dalam pupuk organik padat.

4. Pencampuran pupuk cair organik dengan pupuk organik padat dapat mengaktifkan unsur hara yang ada dalam pupuk organik padat tersebut [10].

Kelebihan dari pupuk organik ini adalah dapat secara cepat mengatasi defesiensi hara, tidak bermasalah dalam pencucian hara, dan mampu menyediakan hara secara cepat. Dibandingkan dengan pupuk cair anorganik, pupuk organik cair umumnya tidak merusak tanah dan tanaman walapun digunakan sesering mungkin. Selain itu, pupuk ini juga memiliki bahan pengikat, sehingga larutan pupuk yang diberikan ke permukaan tanah bisa langsung digunakan oleh tanaman [5]. Pupuk Organik Cair (POC) dalam proses pembuatannya memerlukan waktu yang lebih cepat dari pupuk organic padat, dan penerapannya di pertanian yakni tinggal di semprotkan ke tanaman [8].

\section{Metodologi Penelitian}

Metodologi penelitian dari percobaan ini adalah campuran sisa sayuran sawi, kol, tomat, daun singkong dan kulit pisang dengan berat total 1500 gr di cacah dengan belender hingga halus. Kemudian campuran dimasukkan masing-masing 500 gr kedalam 3 buah galon air 5 liter.

Untuk galon pertama ditambahkan EM4 : 150 $\mathrm{ml}$; Air : 850ml dan Molase : $100 \mathrm{ml}$, galon kedua EM4 : $300 \mathrm{ml}$; Air : $700 \mathrm{ml}$ dan Molase : $100 \mathrm{ml}$ dan galon ketiga EM4 : $500 \mathrm{ml}$; Air : $500 \mathrm{ml}$ dan Molase : $100 \mathrm{ml}$. Diaduk sampai campuran di dalam Galon homogen dan ukur $\mathrm{pH}$ campuran.

Tutup galon dengan penutup yang telah di pasang dengan selang plastik. Kemudian selang plastik di hubungkan ke Gelas Ukur yang terisi air penuh. Selanjutnya inkubasi dan lakukan pengamatan $5 ; 10 ; 15 ; 20$ dan 25 hari hingga diperoleh cairan kental atau pupuk organik cair di dasar galon dan gas yang dihasilkan di dalam Gelas Ukur konstan.

Pupuk organik cair di keluarkan melalui kran yang telah terpasang di galon. Analisa kandungan rasio $\mathrm{C} / \mathrm{N}$; kandungan Carbon, Nitrogen, Phospor dan Kalium, dan Chemical Oxygen Demand pada pupuk organik cair.

\section{Hasil dan Pembahasan \\ Pengaruh Effective Microorganisme 4 terhadap Kualitas Pupuk Cair pada limbah sayur yang di cacah dengan belender \\ Pengaruh Effective Microorganisme 4} terhadap Kualitas Pupuk Cair pada limbah sayur yang dibelender untuk beberapa tabung dengan masing-masing komposisi sayuran ditunjukkan pada gambar 1. 


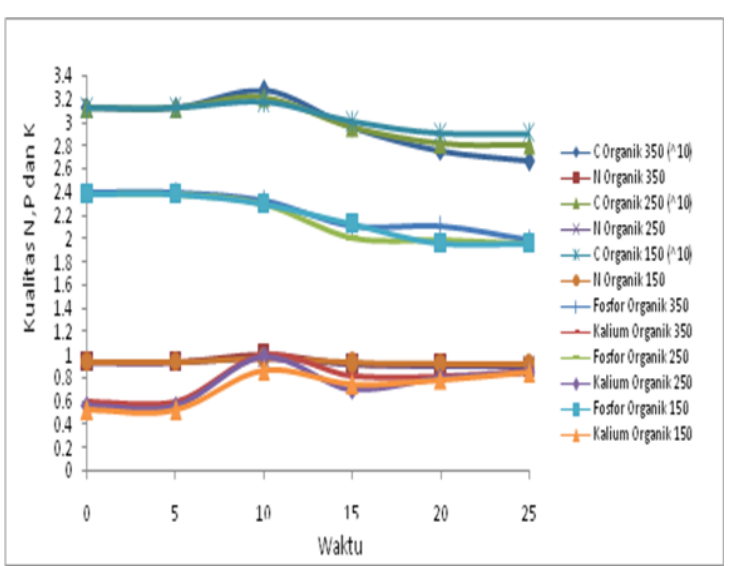

Gambar 1. Hubungan Effective Microorganisme 4 Terhadap Kualitas Pupuk Cair pada Limbah Sayur yang Dicacah dengan Belender.

Dari gambar 1 dapat dilihat bahwa Effective Microorganisme memegang peranan penting dalam kualitas pupuk cair. Dari grafik di dapat kulitas pupuk cair sesuai standart nasional. Namun untuk kualitas yang cukup tinggi dapat dilihat dengan jumlah EM4 $350 \mathrm{ml}$ di hari ke 25 dengan C-organik sebesar 26,66 \% dan Nitrogen sebesar 0,88\%. Untuk Fosfor mengalami penurunan sebesar 1,98\% sedangkan Kalium mengalami kenaikan sebesar $0,85 \%$. Penurunan Fosfor dan kenaikan Kalium ini disebabkan adanya aktifitas mikroba dalam mendekomposisi bahan organik [12]. Dalam kondisi aerob, mikroba memanfaatkan oksigen bebas untuk mendekomposisikan bahan organik dan mengasimilasi sebagian unsur karbon, nitrogen, fosfor, belerang serta unsur lain yang diperlukan untuk mensintesis protoplasma sel mikroba tersebut. Dari hasil yang diperoleh jika dibandingkan dengan penelitian terdahulu menggunakan Effective Microorganisme (EM4) dari limbah sayuran dengan komposisi sayuran sebanyak 500 gr, waktu pengendapan 6 hari, dan $\mathrm{pH} 4$ [14]. Maka, pengunaan Effective Microorganisme (EM4) yang cukup banyak dan fermentasi yang cukup serta ukuran sayuran yang kecil dapat meningkatkan atau mempengaruhi kualitas dari pupuk cair yang dihasilkan [5].

\section{Pengaruh Waktu terhadap Rasio $\mathrm{C} / \mathrm{N}$ pada limbah sayuran yang dibelender \\ Pengaruh waktu terhadap Rasio $\mathrm{C} / \mathrm{N}$ pada limbah sayuran yang dicacah dengan belender untuk beberapa tabung dengan masing-masing komposisi sayuran ditunjukkan pada gambar 2.}

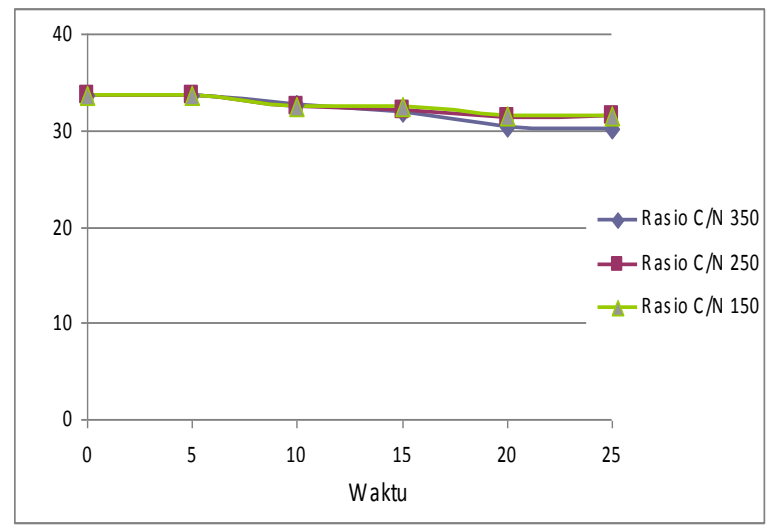

Gambar 2. Hubungan Waktu Terhadap Rasio C/N pada Limbah Sayuran yang Dicacah dengan Belender.

Dari gambar 2 dapat dilihat nilai Rasio C/N. Jika dibandingkan dengan Rasio $\mathrm{C} / \mathrm{N}$ awal sebesar 33,56, maka ada penurunan Rasio C/N. Penurunan terbesar terjadi pada tabung dengan EM4 $350 \mathrm{ml}$ sebesar 30,2. Dan penurunan terendah terjadi pada tabung dengan EM4 $150 \mathrm{ml}$ sebesar 31,55. Terjadinya penurunan nilai Rasio $\mathrm{C} / \mathrm{N}$ dikarenakan selama proses anerobik terjadi pemanfaatan sumber karbon dan nitrogen oleh mikroba. Ini dapat diindikasikan dengan menurunnya nilai $\mathrm{C} / \mathrm{N}$ rasio. Ini menunjukkan terjadi penggunaan atau pemanfaatan sumber karbon dan nitrogen sebagai nutrisi mikroba untuk tumbuh dan berkembang [13]. Perbandingan $\mathrm{C} / \mathrm{N}$ dari bahan organik sangat menentukan aktivitas mikroba dan produksi biogas. Kebutuhan unsur karbon dapat dipenuhi dari karbohidrat, lemak, dan asam-asam organik, sedangkan kebutuhan nitrogen dipenuhi dari protein, amoniak dan nitrat. Perbandingan $\mathrm{C} / \mathrm{N}$ (C/N rasio) substrat akan berpengaruh pada pertumbuhan mikroorganisme [7]. Kesetimbangan karbon dan nitrogen dalam bahan yang digunakan sebagai substrat perlu mendapat perhatian. Oleh karena itu, jika terlalu banyak nitrogen pertumbuhan bakteri akan terhambat, dalam hal ini terutama bahan yang kandungan amonianya sangat tinggi [6]. Berdasarkan beberapa informasi yang diperoleh, agar pertumbuhan bakteri anaerob optimum, diperlukan rasio optimum $\mathrm{C}: \mathrm{N}$ berkisar antara 20 : 1 sampai $30: 1$. Dengan mengacu pada Rasio C/N yang diatur di dalam SNI ataupun KepMenTan tentang kualitas kompos. Di dalam SNI rasio C/N kompos yang diijinkan adalah $10-20$, maka rasio $\mathrm{C} / \mathrm{N}$ yang diperoleh dalam penelitian ini sudah mendekati batas optimum. 


\section{Kesimpulan}

Berdasarkan hasil penelitian pembuatan pupuk cair dengan memanfaatkan limbah sayuran sebagai bahan baku dapat disimpulkan :

1. Pupuk organik cair dapat dihasilkan dengan mengolah limbah sayuran.

2. Untuk hasil yang maksimal diperoleh pada tabung EM4 $350 \mathrm{ml}$ diblender pada hari ke 25 yaitu Rasio C/N 30,22, C-Organik 26,66 \%, Nitrogen 0,88\% dan Biogas $13 \mathrm{ml}$.

3. Ukuran bahan yang lebih kecil, waktu fermentasi yang lama, dan jumlah EM4 yang cukup banyak dapat mempercepat proses pendegradasian dan mempengaruhi kualitas pupuk cair yang dihasilkan.

4. Bahan baku yang dibelender dan dicacah tidak mengalami perbedaan hasil yang cukup signifikan.

\section{Daftar Pustaka}

1. Afifudin, Pengaruh Berbagai Aktivator Terhadap C/N Rasio Kompos Kotoran, Penerbit CV. Sinar Indah, Bogor, 2011.

2. Aldi S, Kompos Kotoran, www.kelinci.blogspot.com pengaruh berbagai aktivator-terhadap-cn.html, diakses pada 1 Februari 2013.

3. Andhika Cahaya, Pembuatan kompos dengan Limbah Padat Organik (Sampah Sayuran dan Ampas Tebu), Tugas Akhir, Jurusan Teknik Kimia UNDIP, 2009.

4. Artiningsih,. Peran Serta Masyarakat dalam Pengelolaan Sampah RumahTangga, http// eprints. undip.ac.id/18387/1/Ni_Komang__Ayu, diakses pada 1 Februari 2012.

5. Bella Shintya, Kompos, http://www.ilmualam. blogspot.com diakses pada 1 Februari 2013.

6. Dewi Lukitaningsih, Bahan Baku Kompos, http://luki2.blog.wordpress.com, diakses pada 1 Februari 2013.

7. Diah Setyorini dkk., Kompos, http://balittanah. litbang.deptan.go.id/dokumentasi/buku/pupuk/pupuk 2.pdf diakses pada 22 Februari 2013.

8. Dieyna, Analisis Kadar Air, http://mizuc.blogspot. com/2012/11/analisis-kadar-air.html, diakses pada 1 Februari 2013.

9. Elmi Sundari, Ellyta Sari, Riko Rinaldo, Pembuatan Pupuk Organik Cair Menggunakan Bioaktivator Biosca dan EM4, Prosiding SNTK TOPI 2012, Pekanbaru 11 Juli 2012.

10. Endang Yulistiawati, Pengaruh Suhu dan C/N Rasio Terhadap Produksi Biogas Berbahan Baku Sampah, Skripsi S1, Jurusan Teknologi Pertanian IPB, 2008.

11. Esther L. Tobing, Studi Tentang Kandungan Nitrogen, Karbon (C) Organik dan C/N dari Kompos Tumbuhan Kembang Bulan (Tithonia diversifolia), Skripsi, Departemen Kimia, Fakultas Matematika dan
Ilmu Pengetahuan Alam, Universitas Sumatera Utara, Medan, 2009.

12. Nurhasanah, Perkembangan Digester Biogas di Indonesia, Studi Kasus di Jawa Barat dan Jawa Tengah, Balai Besar Pengembangan Mekanisasi Pertanian, Bandung, 2006.

13. Simamora, Suhut, dan Salundik., Meningkatkan Kualitas Kompos, Harian Analisa, Medan, 12 Februari 2006.

14. Yulya Fitria, Pembuatan Pupuk Organik Cair dari Limbah Cair Industri Perikanan Menggunakan Asam Asetat dan EM4, Skripsi Teknologi Hasil Perikanan IPB, Bogor, 2008. 